\title{
Review
}

\section{STING Signaling and Skin Cancers}

\author{
Sayaka Sato, Yu Sawada * and Motonobu Nakamura
}

check for

updates

Citation: Sato, S.; Sawada, Y.; Nakamura, M. STING Signaling and Skin Cancers. Cancers 2021, 13, 5603. https://doi.org/10.3390/ cancers 13225603

Academic Editor: Alfonso Baldi

Received: 29 September 2021

Accepted: 8 November 2021

Published: 9 November 2021

Publisher's Note: MDPI stays neutral with regard to jurisdictional claims in published maps and institutional affiliations.

Copyright: (c) 2021 by the authors. Licensee MDPI, Basel, Switzerland. This article is an open access article distributed under the terms and conditions of the Creative Commons Attribution (CC BY) license (https:/ / creativecommons.org/licenses/by/ $4.0 /)$.
Department of Dermatology, University of Occupational and Environmental Health, 1-1 Iseigaoka, Yahatanishi-Ku, Kitakyushu 807-8555, Japan; sato-sayaka@med.uoeh-u.ac.jp (S.S.); motonaka@med.uoeh-u.ac.jp (M.N.)

* Correspondence: long-ago@med.uoeh-u.ac.jp

Simple Summary: Stimulator of interferon genes (STING) is currently recognized as a driver for anti-tumor immunity against various malignancies and is expected to enhance the anti-tumor effects. In this review, we summarized recent knowledges gained from epigenetics-mediated skin cancer development and discussed the clinical application of STING agonists in the treatment of skin cancer.

Abstract: Recent developments in immunotherapy against malignancies overcome the disadvantages of traditional systemic treatments; however, this immune checkpoint treatment is not perfect and cannot obtain a satisfactory clinical outcome in all cases. Therefore, an additional therapeutic option for malignancy is needed in oncology. Stimulator of interferon genes (STING) has recently been highlighted as a strong type I interferon driver and shows anti-tumor immunity against various malignancies. STING-targeted anti-tumor immunotherapy is expected to enhance the anti-tumor effects and clinical outcomes of immunotherapy against malignancies. In this review, we focus on recent advancements in the knowledge gained from research on STING signaling in skin cancers. In addition to the limitations of STING-targeted immunotherapy, we also discuss the clinical application of STING agonists in the treatment of skin cancer.

Keywords: STING; skin cancers; IFN; epigenetics

\section{Introduction}

Immune cells circulate in the human body for protection against external stimuli, such as antigens and microorganisms, by innate immunity and antigen-specific acquired immune responses [1,2]. Tumor cells are also recognized by host immune cells, and the importance of anti-tumor immune reactions to eradicate malignancies has been identified for a long time in the clinical scenario [3]. In particular, acquired immune responses contribute to anti-tumor immunity against malignancies mediated by cytotoxic reactions to tumor cells $[4,5]$. In contrast, immune cells face some difficulty in exerting anti-tumor immune responses to malignant tumor cells. One of the representative reasons is that tumor cells establish a clever escape strategy from anti-tumor immunity mediated by the signaling of PD-1/PD-L1 or CTLA-4 [6,7]. Theoretically, we expect to observe a sufficient anti-tumor immune response to malignancies by immune checkpoint inhibitor treatment; however, this treatment is not perfect, and it has been unable to obtain a satisfactory clinical outcome in all cases [6,7]. Therefore, an additional therapeutic option for malignancy is currently needed in oncology.

Type I interferon (IFN) is a representative inflammatory cytokine that activates the acquired immune response mediated by antigen-presenting cells and subsequently drives cytotoxic cell expansion and activation $[8,9]$. Type I IFN is currently used to treat malignancies $[10,11]$. However, the currently used type I IFN treatment does not yield sufficient therapeutic outcomes. Therefore, a more potent type I IFN driver might have a beneficial impact on the treatment of malignancies.

Among various type I IFN-inducible candidates, stimulator of IFN genes (STING) has been recently recognized as a strong type I IFN driver and it has shown anti-tumor 
immunity against various malignancies $[12,13]$. STING is activated by external stimuli, such as viruses, and leads to the enhancement of IFN- $\beta$-mediated augmentation of immune responses. Therefore, STING-targeted anti-tumor immunotherapy is highlighted by clinicians as an enhancer of the anti-tumor effects and clinical outcomes of immunotherapy against malignancies. However, there are only a limited number of review papers in dermatology.

In the present review, we focus on recent advancements in the knowledge gained from research regarding STING signaling in skin cancers. In addition to the limitations of STING-targeted immunotherapy, we also discuss the clinical application of STING agonists in skin cancer immunotherapy in the future.

\section{The Mechanism of STING Signaling}

STING is a crucial positive immune driver that induces the production of type I IFN by triggering intracellular pathogens, such as viruses [14]. STING-mediated type I IFN promotes the activation of acquired immune responses mediated by antigen-presenting cells and enhances downstream cytotoxic immune reactions [9].

As an activation mechanism, cytosolic DNA becomes a trigger for the activation of cGAS-cGAMP-STING signaling [15-17] (Figure 1). Cytoplasmic DNA is a danger signal that is released from the nucleus and mitochondria, or by the induction of viruses or bacteria [14]. These released cytosolic DNAs, such as double-strand DNA (dsDNA) or single-strand DNA (ssDNA), are detected by a DNA sensor protein, cGAS, which enhances the synthase of $2^{\prime} 3^{\prime}$-cyclic GMP-AMP $\left(2^{\prime} 3^{\prime}\right.$-cGAMP). cGAMP acts as a second messenger for STING activation [15-19]. dsDNA acts upstream of STING on cGAS, while bacteria can also generate CDNs and activate STING independently of cGAS [20-22]. STING consists of four transmembrane domains located in the endoplasmic reticulum (ER). After cGAMP binds to STING, STING translocates to the perinuclear site and drives the downstream cascade. STING positively regulates the downstream pathway and activates the transcription factor interferon regulatory factor 3 (IRF3) and signal transducer and activator of transcription 6 (STAT6) through TANK-binding kinase 1 (TBK1). STING activates TBK1 to enhance the phosphorylation of IRF3 or STAT6, which enters the nucleus to promote the transcription of type I IFN. Type I IFN enhances antigen presentation ability and T-cell proliferation in the skin $[8,9]$ (Figure 2). To drive anti-tumor acquired immune responses, antigen-presenting cells, especially dendritic cells, recognize antigens on the surface of skin cancers, and migrate to draining lymph nodes to present antigens to naïve T-cells for the induction of antigen-specific reactive T-cells $[23,24]$. Tumor antigen-specific T-cells drive anti-tumor immune responses mediated mainly by cytotoxic reactions. Therefore, these signaling effects are expected to elicit an anti-tumor immune response against skin cancers.

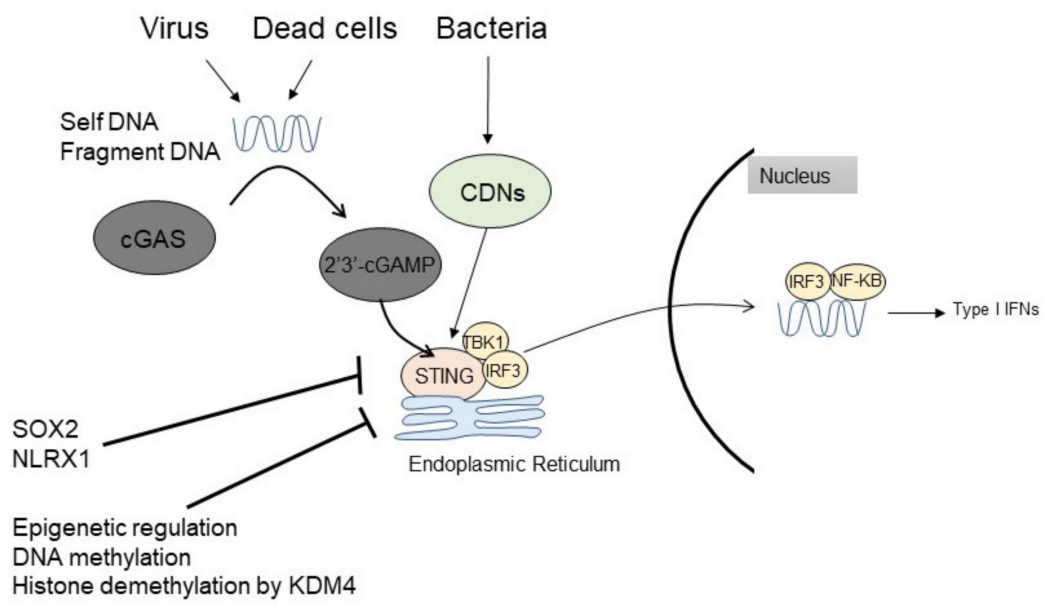

Figure 1. Pathway of STING signaling and anti-tumor immunity. Cytosolic DNA triggers the activation of cGAS-cGAMP-STING signaling. Cytosolic DNA is detected by a DNA sensor protein, 
cGAS, which enhances the synthase of $2^{\prime} 3^{\prime}$-cyclic GMP-AMP $\left(2^{\prime} 3^{\prime}\right.$-cGAMP). cGAMP plays as a second messenger for the activation of STING. Bacteria can also generate CDNs and activate STING independently of cGAS. STING activates transcription factors IRF3 and STAT6 through TBK1 and promotes the gene transcription of type I IFN. DNA: deoxyribonucleic acid, cGAS: cyclic GMP-AMP synthase, CDNs: cyclic dinucleotides, STING: Stimulator of IFN genes; TBK1: tank binding kinase 1; IRF3: interferon regulatory factor 3, NF-kB: nuclear factor-kappa B; IFN: interferon; SOX: SRY-box transcription factors; NLRX1: NLR Family Member X1.

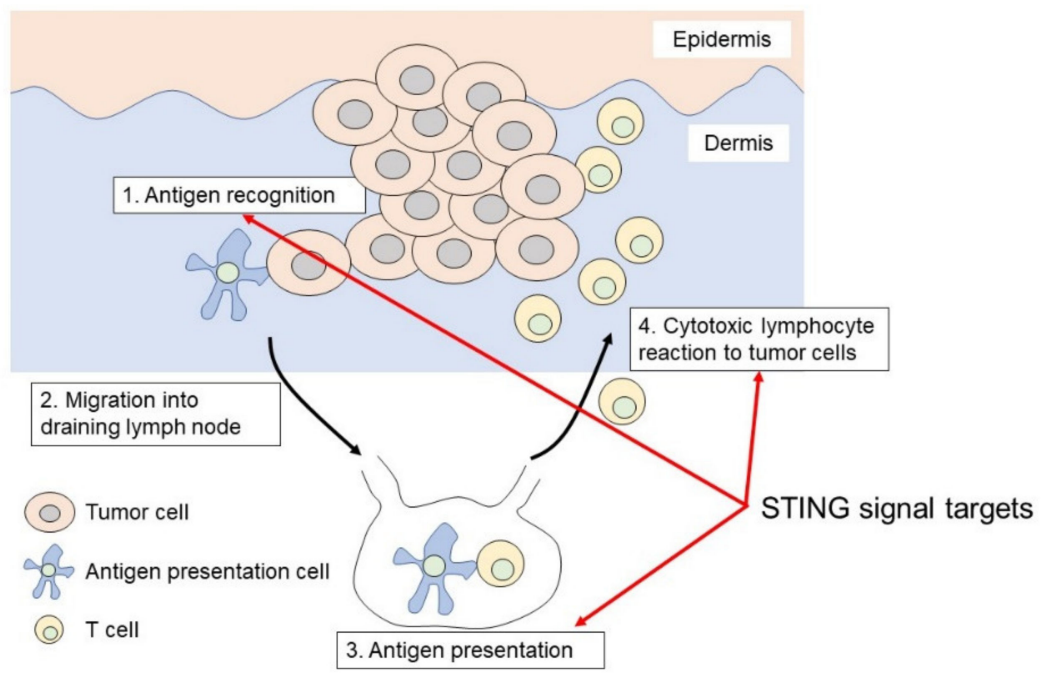

Figure 2. Cutaneous immune responses against tumor cells. Antigen-presenting cells, especially dendritic cells, recognize antigens on the surface of skin cancers, and migrate to draining lymph nodes to present tumor antigens to naïve T-cells for the induction of antigen-specific reactive T-cells. These tumor antigen-specific T-cells react to tumors to drive an anti-tumor immune response.

In addition, the STING signaling pathway plays an important role in various skin diseases. Keratinocytes are major constitutive cells in the epidermis and regulate inflammatory responses against external environmental stimuli involved in various inflammatory skin diseases [25-28]. The characteristics of the keratinocytes located in the outermost layer of the skin suggest they can be influenced by external organisms to induce inflammatory cytokine production. Cytosolic DNA induces weak inflammatory responses in keratinocytes; however, these effects are synergized with TNF- $\alpha$ and IL-1 $\beta$ [29]. Therefore, STING signaling may be involved in various inflammatory processes under certain inflammatory skin conditions. Indeed, STING signals enhance the degree of inflammation in skin diseases, such as psoriasis [30], acne [31], and hidradenitis suppurativa [32]. Therefore, the skin is expected to be influenced by STING signaling.

\section{STING-Involved Anti-Tumor Immunity}

There are recent updates in the research on STING in skin cancers. In this section, we refer to skin malignancies in the detailed molecular mechanism of STING-mediated anti-tumor immunity, such as melanoma, squamous cell carcinoma, Merkel cell carcinoma, and adult T-cell leukemia/lymphoma.

\subsection{Melanoma}

Melanoma is a malignancy derived from melanocytes that shows unfavorable clinical outcomes following current treatment [33]. Recent advancements in immune checkpoint inhibitor treatment or BRAF-mutation targeted inhibitors dramatically overcome the limitations of current treatments and yield favorable clinical outcomes [34-36]. However, intractable cases of these novel treatments do exist in patients with melanoma. Therefore, STING-targeted treatment is currently seen as a possible alternative or additive treatment for melanoma. 
STING enhances anti-tumor immunity against melanoma mediated by IFN [37-41], which activates immune cells such as CD11c+ DC, CD8+ cells and NK cells in response to melanoma cells [42-44]. STING also upregulates MHC class I molecules, thereby enhancing the recognition or killing effect of cytotoxic T-cells [45]. A STING stimulator, cGAMP, injection into the tumor leads to the activation of STING, subsequently enhancing CD8+ cell infiltration into the tumor and suppressing tumor growth [46]. STING also enhances chemokines, such as CXCL10, CCL5, and IL-33, which also contribute to the infiltration of NK cells [47]. STING induces the production of TNF- $\alpha$, which is essential for anti-tumor immunity [48].

Several studies suggest a potent additional therapeutic effect of STING signaling in combination with immunotherapy. cGAS-deficient mice showed impaired growth of B16 melanomas in response to PD-L1 antibody treatment [49]. Depletion of CD8+ T-cells or $\mathrm{M} \varphi$ impaired the anti-tumor effects of cGAMP treatment [50]. In addition, CAR-T cell treatment eradicates tumors more effectively with STING agonists that stimulate immune responses to eliminate tumor cells [51].

STING is also responsible for the efficacy of chemotherapy in melanoma. 5-fluorouracil (5-FU) is a representative chemotherapeutic agent, and its responsiveness depends on intrinsic STING signaling in tumor cells and subsequent type I IFN production. Consistently, the deficiency of STING in tumor cells is related to the requirement of a higher dose of 5-FU to exert anti-tumor effects [52].

Radiation is one of the therapeutic options for melanoma treatment, and combination therapy with an immune checkpoint inhibitor is expected to show abscopal effects against melanoma [53]. Consistently, inhibition of pattern recognition by STING signaling negatively regulates type 1 IFN production and prevents the regression of abscopal tumors by treatment with radiation and an immune checkpoint blockade [54]. Since the NF- $\mathrm{B}$ pathway supports the initiation and progression of tumors, this pathway involves the mechanisms of radiotherapy resistance of tumor cells. The deficiency of non-canonical NF- $\kappa B$ activates radiation-induced anti-tumor immunity mediated by the STING sensordependent DNA-sensing pathway, triggering DC activation [55]. Therefore, STING is also involved in resistance to radiotherapy.

\subsection{Cutaneous Squamous Cell Carcinoma}

Cutaneous squamous cell carcinoma is a skin cancer derived from epithelial keratinocytes, and its advanced form has an unfavorable clinical course because of the limited number of therapeutic options in the current treatment [56-58]. In addition, immune checkpoint inhibitor treatment is not widely used for treating metastatic cutaneous squamous cell carcinoma. Therefore, clinicians need novel treatment options for cutaneous squamous cell carcinoma.

STING has been identified as an intrinsic regulator of squamous cell carcinoma survival $[59,60]$. STING positively regulates the generation of reactive oxygen species (ROS), and STING reduction impairs DNA damage, leading to therapeutic resistance. Consistently, low STING expression in squamous cell carcinoma is associated with unfavorable clinical behavior. The pharmacological activation of STING enhances anti-tumor effects by combining DNA-damaging agents [59]. STING induces type 1 IFN and CD8+ T-cellmediated anti-tumor immunity [61], and enhances the production of immunosuppressive cytokines and impairs the infiltration of regulatory T-cells [62].

In contrast, cytosolic DNA triggers chromosomal instability in tumor cells and enhances tumor metastasis. This depends on the activation of cGAS-STING signaling by cytosolic DNA-sensing stimulation [63].

Activated-STING increases IFN production and enhances the expression of PD-1 pathway in vivo [59]. STING is also a positive driver of chemotherapy-induced anti-tumor immunity. Combination therapy using cisplatin and cGAMP enhances the gene expression of CXCL9 and CXCL10 in tumor tissues and inhibits tumor growth [64]. STING promotes the cetuximab-induced activation of NK cells and DCs [65]. 


\subsection{Merkel Cell Carcinoma}

Merkel cell carcinoma is a rare cutaneous malignancy derived from neuroendocrine cells, and Merkel cells act as mechanoreceptors. Merkel cell carcinoma exhibits aggressive clinical behavior with a high mortality rate. Elderly and immunocompromised host conditions contribute to the development of Merkel cell carcinoma. Although there are a limited number of therapeutic options for Merkel cell carcinoma with distant metastasis and immune checkpoint inhibitor treatment, avelumab shows favorable clinical outcomes. Therefore, anti-tumor immunity against Merkel cell carcinoma is needed as an additional therapeutic option.

The Merkel cell polyoma virus plays an important role in the oncogenesis of Merkel cell carcinoma, and its replication and / or transcription drive an innate immune response via cGAS-STING [66]. Furthermore, STING is completely silenced in Merkel cell carcinomas [67]. STING deficiency contributes to the immunosuppressive nature of Merkel cell carcinoma. STING agonists enhance cell death in Merkel cell carcinoma in addition to DNA released by the dying cancer cells, which enhances the innate immune response and activates antitumor adaptive responses. Therefore, STING signaling in Merkel cell carcinoma plays an important role in anti-tumor immunity.

\subsection{Adult T-Cell Leukemia/Lymphoma}

Adult T-cell leukemia/lymphoma is a malignancy associated with human T-cell lymphotropic virus type I (HTLV-1)-infected mature CD4+ T-cells [68,69]. Adult T-cell leukemia/lymphoma is divided into four clinical groups according to Shimoyama's classification based on the severity, number of abnormal lymphocytes, and organ involvement [69]. Skin lesions are observed in approximately $50 \%$ of adult T-cell leukemia/lymphoma patients, and the assessment of skin lesions is helpful in prognosis [70-72]. Although aggressive types, namely the acute and lymphoma types of adult T-cell leukemia/lymphoma, show an unfavorable clinical course [73-75], the chronic and smoldering types are indolent and can usually be managed by "watchful waiting" [76].

IFN is a key therapeutic target for the innate immune response to viruses. IFN- $\alpha$ is a standard therapeutic option for adult T-cell leukemia/lymphoma with a combination of the nucleoside reverse transcriptase inhibitor zidovudine. Tax expression, which is responsible for the development of adult T-cell leukemia/lymphoma, suppresses the induction of IFN production by cGAMP synthase plus STING stimulation [77]. STING enhances the formation of a complex of IRF3-Bax leading to adult T-cell leukemia/lymphoma apoptosis, suggesting that STING is responsible for anti-tumor activity against adult T-cell leukemia/lymphoma [78].

\subsection{STING Anti-Tumor Effect Expected Skin Cancers}

Although there have been no reports regarding the relationship between STING and its downstream cytokines, these are involved in the suppression of basal cell carcinoma [79-81], diffuse large B-cell lymphoma [82], mycosis fungoides [83-90], and Sézary syndrome [83-85,91-95]. Therefore, these cutaneous malignancies are expected to have a beneficial effect on STING-mediated anti-tumor effects.

\subsubsection{Basal Cell Carcinoma}

Basal cell carcinoma is a malignancy arising from the epidermal basal cells [96]. Although basal cell carcinoma shows local invasion, metastasis is a rare event. There are some drugs, such as a hedgehog signaling pathway inhibitor, but these have not achieved successful outcomes. Due to the limited number of therapeutic options for metastatic basal cell carcinoma in such rare cases, a therapeutic candidate for anti-tumor immune responses against basal cell carcinoma has been required for a long time.

IFN- $\alpha$ injection into the tumor is effective in basal cell carcinoma [79]. IFN- $\alpha$ induces the expression of Fas in basal cell carcinoma leading to apoptosis of the tumor [80], suggesting that type I IFN plays an important role in the regulation of basal cell carcinoma. 
In addition, a previous study reported that IFN- $\gamma$ increased in spontaneously regressing basal cell carcinoma, suggesting that cytotoxic immune reaction-mediated Th1 might play a pivotal role in the regulation of basal cell carcinoma [81]. STING drives the downstream immune reaction mediated by CD8+ T-cells, which produce an abundance of IFN- $\gamma$, and is expected to have beneficial therapeutic effects.

\subsubsection{Cutaneous Lymphomas}

Diffuse large B-cell lymphoma is a malignancy of B-cells and it is a common type of non-Hodgkin cutaneous lymphoma [97]. Cutaneous diffuse large B-cell lymphoma is commonly observed in the extremities and clinically appears as solid nodules or tumors in the skin. In addition to the specific therapeutic approach for diffuse large B-cell lymphoma targeting CD20 cell surface markers, immunotherapy is currently highlighted as an alternative treatment option for clinicians.

Although there have been no reports regarding STING and diffuse large B-cell lymphoma, IFNs have been used for treatment. Among IFNs, IFN- $\beta$ shows more potent direct suppressive effects on tumor cell growth by inducing apoptotic cell death following DNA damage, caspase- 3 activation, and the annexin V binding effect [82]. Therefore, STINGmediated IFN is expected to show anti-tumor effects on diffuse large B-cell lymphoma.

Mycosis fungoides are malignant tumors of $\mathrm{T}$ lymphocytes with epidermotropism in the skin [68,98-101]. Mycosis fungoides exhibits an indolent clinical course with a slow advancement starting from patches to plaques and eventually developing into nodules/tumors as a more infiltrated form [68]. The prognosis of mycosis fungoides is closely related to the clinical stage, skin involvement, and systemic organ involvement [68].

Several studies have shown the therapeutic effects of IFN- $\alpha$ on mycosis fungoides [83]. IFN- $\alpha$ enhances anti-tumor effects in combination with chemotherapy, phototherapy, and anti-CCR4 antibody treatment [84-86]. Topical IFN- $\beta$ showed therapeutic potential for mycosis fungoides and showed rapid tumor resolution [87]. Furthermore, intratumoral IFN- $\gamma$ administration has a therapeutic effect on mycosis fungoides [88-90].

Sézary syndrome is a $\mathrm{T}$ lymphocyte-derived malignancy characterized by erythroderma as a clinical manifestation $[98,99,102]$. Although STING-mediated anti-tumor effects have not been reported in patients with Sézary syndrome, the downstream of STING signaling IFNs have also been investigated as a therapeutic option for Sézary syndrome. IFN- $\alpha$ is effective for Sézary syndrome [91] and the combination of IFN- $\alpha$ and chemotherapy or phototherapy shows more potent therapeutic effects [83-85,92-94]. IFN- $\gamma$ also enhances cytotoxic activity against tumor cells in Sézary syndrome [95]. Therefore, these findings suggest that STING-mediated anti-tumor immune reactions might be beneficial for the treatment of Sézary syndrome.

Other effects of IFNs are those against tumor and anti-tumor immune responses. IFN$\alpha / \beta$ enhances immunoglobulin production by B-cells. IFN- $\gamma$ enhances NK cell activity, suppresses tumor growth, and reduces IL-4 production in patients with mycosis fungoides. Therefore, STING-targeted treatment is expected to show the effect of these downstream cytokines on mycosis fungoides.

\section{STING Strategy for Skin Cancers}

To obtain a more potent anti-tumor effect mediated by the STING signal, some modifications of the STING stimulator have been investigated. Cationic liposomes with varying surface polyethylene glycol (PEG) are used to encapsulate cGAMP to facilitate its cytosolic delivery, and antigen-presenting cells improve the cellular uptake of cGAMP and pro-inflammatory gene induction [103]. Biodegradable poly(beta-amino ester) (PBAE) nanoparticles to deliver CDNs for STING agonists synergize with checkpoint inhibitors and have strong potential to enhance cancer immunotherapy [104]. cGAMP encapsulated in lipid nanoparticles conjugated with mannose (LP-cGAMP) was designed for delivery to DCs. LP-cGAMP potently drives STING-mediated inflammatory reactions and subsequently enhances CD8+ T-cell infiltration. Consistently, STING activation upregulates 
PD-L1 on tumor cells and has a beneficial impact on the anti-tumor immune response in B16F10 and BRAF-mutated murine melanoma animal models [105]. Microfabricated polylactic-co-glycolic acid (PLGA) particles encapsulated a STING agonist that triggers anti-tumor immune reactions to suppress tumor growth and have a beneficial impact on their survival. STING agonist-loaded microparticles improve the response to immune checkpoint blockade therapy [106].

In addition, several novel STING agonists have been developed for melanoma treatment. Manganese potentiates the anti-tumor immune response as a STING agonist [107]. Dimeric aminobenzimidazole (diABZI) is another STING agonist that promotes tumor cell death in melanoma in combination with BRAF inhibitors [108]. Cytomegalovirus (CMV) acts as a STING agonist in tumors. CMV-infected tumors in STING-deficient mice show no additional immune reactions, such as macrophage and CD8+ T-cell infiltration and decreased inflammatory cytokine and chemokine production [109]. Two highly potent cyclic dinucleotide STING agonists, IACS-8803 and IACS-8779, were developed as STING agonists and enhanced systemic anti-tumor responses in a B16 murine model of melanoma [110]. Haspin kinase (HASPIN) is related to the regulation of STING signaling; therefore, HASPIN inhibition reduces proliferation of the tumor cells by the activation of the STING pathway and STING-dependent type I IFN and decreased Treg [111]. ADU-S100 is a STING agonist [112] and it has anti-tumor effects in cervical cancer [113], pancreatic cancer [114], esophageal adenocarcinoma [115], and prostate cancer. Therefore, this analog is expected to have anti-tumor effects against cutaneous malignancies.

Combination therapy with STING has been proposed for the treatment of melanoma. The phagocytosis checkpoint of signal regulatory protein $\alpha(\operatorname{SIRP} \alpha)$ and STING in antigen presentation cells enhance the anti-tumor immune response [116]. STING signaling activates antigen-presenting cells to induce the activation of CD8+ cells. In addition, a nanoparticle combined with TLR9, STING, and RIG-I with a melanoma-specific peptide enhances the anti-tumor immune response [117].

There are several reports on STING-targeted therapeutic options. SOX2 acts as a STING inhibitor. SOX2 enhances STING degradation in an autophagy-dependent manner and subsequently suppresses the production of type I IFN. Consistently, SOX2 supports squamous cell carcinoma cell growth by suppressing anti-tumor immunity. A combination of a STING agonist with anti-PD-L1 antibody treatment enhances the tumor-specific cytotoxic lymphocyte reaction, thereby improving survival [118]. NLRX1 is a mitochondrial NOD-like receptor that enhances the NF- $k B$ and JNK pathways through the production of ROS. NLRX1 promotes HPV16 E7-potentiated STING turnover. Consistently, NLRX1 depletion activates type I IFN-dependent T-cell infiltration profiles and tumor control [119].

\section{Epigenetic Modification}

Epigenetic changes are chemical modifications of DNA and DNA-binding histones, which can modulate chromatin structure and gene transcription by exposure to environmental stimuli without changing DNA sequence information [120].

STING signaling is not suitable for melanoma cells in terms of long-term tumor development because it triggers anti-tumor immunity. As one of the strategies for melanoma development, STING is suppressed in melanoma cells by epigenetic silencing of STING and cyclic GMP-AMP synthase [121], possibly due to suppressed DNA hypermethylation in melanoma cells. The presence of considerable CpG islands within the STING and cGAS promoter regions contributes to the epigenetic regulation of STING in melanoma cells. Indeed, a demethylase, 5AZADC, treated melanoma cells following dsDNA stimulation and showed recovered IFN- $\beta$ and CXCL10 production in melanoma cells suggesting that DNA methylation might play a role in the regulation of STING in melanoma. In addition, as another mechanism to suppress STING signaling, STING signaling may be commonly suppressed in a greater variety of tumors due to loss-of-function mutations or epigenetic silencing of the STING/cGAS promoter regions [122]. 
In the STING modification of epigenetic changes in squamous cell carcinoma, KDM4A inhibition activates immune responses to squamous cell carcinoma and enhances the therapeutic potential of anti-PD-1 antibody treatment for squamous cell carcinoma. KDM4A is a histone demethylase that targets histone $\mathrm{H} 3$ lysine 9 trimethylation (H3K9me3) and is associated with the development of squamous cell carcinoma growth and metastasis. KDM4A inhibition activates cGAS-STING signaling in tumor cells. Consistently, KDM4A inhibition with the combination of anti-PD-1 antibody treatment suppresses tumor growth and metastasis [123], suggesting that epigenetic modification of STING signaling mediated by KDM4A histone demethylation might positively drive anti-tumor immunity.

\section{Limitations and Disadvantages of STING-Mediated Anti-Tumor Immunity}

Although STING is anticipated as an additional immunotherapy treatment against skin cancers, downstream cytokines of IFNs are needed to boost immunotherapy against cancers. However, IFN-treated patients did not exhibit the dramatic therapeutic potential of IFN- $\beta$ during the treatment of skin cancers. Therefore, it seems that STING might not show satisfactory clinical outcomes in all cases as a driver of the anti-tumor immune reaction to skin cancers.

The current administration of IFN- $\beta$ transiently increases its concentration in the human body. Therefore, sustainable IFN- $\beta$ production from the host might have more potent anti-tumor effects against skin cancers. As so, STING agonist administration can drive IFNs; however, the treatment itself might limit the transient production of IFNs.

Because various cells can react with IFNs, it is important for IFNs to react to anti-tumor immune cell-specific or tumor sites to obtain the maximum effects of STING. Therefore, systemic STING agonists might result in the same pitfall as systemic IFN treatment or subcutaneous injection of IFNs. A recent study identified that IFN-independent STING signaling enhances autophagy [124], which can enhance anti-tumor immune responses. In addition, STING signaling triggers DNA damage response to tumor cells $[125,126]$ and MHC class I expression in tumor and immune cells [127]. These additive non-IFN-independent effects of STING might also contribute to the development of anti-tumor responses.

In addition, STING signaling activation might result in the enhancement of autoimmune reactions, as seen in immune checkpoint inhibitor treatment. STING activation has been observed in various autoimmune diseases, such as rheumatoid arthritis [128] and dermatomyositis [129]. Therefore, clinicians should keep in mind that STING-mediated anti-tumor therapy might show immune cell-mediated adverse event (irAE) reactions during treatment [130]. Furthermore, combination therapy with immune checkpoint inhibitors will be a therapeutic option for malignancies; however, a more potent risk of severe irAEs will need to be discussed in the future. As a strategy against STING-triggered irAEs, corticosteroids might be the first approach to suppress the symptoms of adverse reactions of STING-mediators. In addition, downstream cytokine suppression might also be a candidate for the treatment of STING-mediated irAEs. Anti-IFN antibodies are currently used for various treatments [131]; therefore, these agents may also be used for STING-mediated irAE treatment.

\section{Conclusions}

STING is anticipated as a therapeutic candidate for the treatment of an advanced form of skin cancer; however, it remains unclear whether STING signaling is involved in the regulation of tumor development. On the other hand, STING-targeted treatment might have disadvantages, possibly autoimmune-mediated systemic reactions, indicating that clinicians might keep in mind this advantage of STING-targeted treatment for skin cancers. Furthermore, STING-mediated inflammation may also contribute to the development of another malignancy [132]. Given that there is a large frontier field regarding STINGmediated anti-tumor function in skin cancers, further investigation is required to clarify the detailed roles of STING in skin cancer. 
Author Contributions: Conceptualization, S.S. and Y.S.; methodology, S.S., Y.S.; writing-original draft preparation, S.S. and Y.S.; writing-review and editing, M.N.; visualization, S.S.; funding acquisition, Y.S. All authors have read and agreed to the published version of the manuscript.

Funding: This research was supported by the Japanese Dermatology Association (Novartis Pharma donated).

Conflicts of Interest: The authors declare no conflict of interest.

\section{References}

1. Kabashima, K.; Honda, T.; Ginhoux, F.; Egawa, G. The immunological anatomy of the skin. Nat. Rev. Immunol. 2019, 19, 19-30. [CrossRef] [PubMed]

2. Dainichi, T.; Kitoh, A.; Otsuka, A.; Nakajima, S.; Nomura, T.; Kaplan, D.H.; Kabashima, K. The epithelial immune microenvironment (EIME) in atopic dermatitis and psoriasis. Nat. Immunol. 2018, 19, 1286-1298. [CrossRef] [PubMed]

3. McGovern, V.J. Spontaneous regression of melanoma. Pathology 1975, 7, 91-99. [CrossRef] [PubMed]

4. Iwai, Y.; Hamanishi, J.; Chamoto, K.; Honjo, T. Cancer immunotherapies targeting the PD-1 signaling pathway. J. Biomed. Sci. 2017, 24, 26. [CrossRef]

5. Chamoto, K.; Hatae, R.; Honjo, T. Current issues and perspectives in PD-1 blockade cancer immunotherapy. Int. J. Clin. Oncol. 2020, 25, 790-800. [CrossRef]

6. Hodi, F.S.; Chesney, J.; Pavlick, A.C.; Robert, C.; Grossmann, K.F.; McDermott, D.F.; Linette, G.P.; Meyer, N.; Giguere, J.K.; Agarwala, S.S.; et al. Combined nivolumab and ipilimumab versus ipilimumab alone in patients with advanced melanoma: 2-year overall survival outcomes in a multicentre, randomised, controlled, phase 2 trial. Lancet Oncol. 2016, 17, 1558-1568. [CrossRef]

7. Goldberg, S.B.; Gettinger, S.N.; Mahajan, A.; Chiang, A.C.; Herbst, R.S.; Sznol, M.; Tsiouris, A.J.; Cohen, J.; Vortmeyer, A.; Jilaveanu, L.; et al. Pembrolizumab for patients with melanoma or non-small-cell lung cancer and untreated brain metastases: Early analysis of a non-randomised, open-label, phase 2 trial. Lancet Oncol. 2016, 17, 976-983. [CrossRef]

8. Zhang, L.J.; Sen, G.L.; Ward, N.L.; Johnston, A.; Chun, K.; Chen, Y.; Adase, C.; Sanford, J.A.; Gao, N.; Chensee, M.; et al. Antimicrobial Peptide LL37 and MAVS Signaling Drive Interferon- $\beta$ Production by Epidermal Keratinocytes during Skin Injury. Immunity 2016, 45, 119-130. [CrossRef]

9. Sawada, Y.; Nakatsuji, T.; Dokoshi, T.; Kulkarni, N.N.; Liggins, M.C.; Sen, G.; Gallo, R.L. Cutaneous innate immune tolerance is mediated by epigenetic control of MAP2K3 by HDAC8/9. Sci. Immunol. 2021, 6, 59. [CrossRef]

10. Clifford, J.L.; Menter, D.G.; Yang, X.; Walch, E.; Zou, C.; Clayman, G.L.; Schaefer, T.S.; El-Naggar, A.K.; Lotan, R.; Lippman, S.M. Expression of protein mediators of type I interferon signaling in human squamous cell carcinoma of the skin. Cancer Epidemiol. Biomark. Prev. 2000, 9, 993-997.

11. Karavodin, L.M.; Golub, S.H. Systemic administration of human leukocyte interferon to melanoma patients. III. Increased helper:suppressor cell ratios in melanoma patients during interferon treatment. Nat. Immun. Cell Growth Regul. 1983, 3, 193-202. [PubMed]

12. Bronte, V. Tumors STING adaptive antitumor immunity. Immunity 2014, 41, 679-681. [CrossRef]

13. Chandra, D.; Quispe-Tintaya, W.; Jahangir, A.; Asafu-Adjei, D.; Ramos, I.; Sintim, H.O.; Zhou, J.; Hayakawa, Y.; Karaolis, D.K.; Gravekamp, C. STING ligand c-di-GMP improves cancer vaccination against metastatic breast cancer. Cancer Immunol. Res. 2014, 2, 901-910. [CrossRef] [PubMed]

14. Xiao, Q.; McAtee, C.K.; Su, X. Phase separation in immune signalling. Nat. Rev. Immunol. 2021. [CrossRef] [PubMed]

15. Jiang, M.; Chen, P.; Wang, L.; Li, W.; Chen, B.; Liu, Y.; Wang, H.; Zhao, S.; Ye, L.; He, Y.; et al. cGAS-STING, an important pathway in cancer immunotherapy. J. Hematol. Oncol. 2020, 13, 81. [CrossRef]

16. Wan, D.; Jiang, W.; Hao, J. Research Advances in How the cGAS-STING Pathway Controls the Cellular Inflammatory Response. Front. Immunol. 2020, 11, 615. [CrossRef]

17. Corrales, L.; McWhirter, S.M.; Dubensky, T.W., Jr.; Gajewski, T.F. The host STING pathway at the interface of cancer and immunity. J. Clin. Investig. 2016, 126, 2404-2411. [CrossRef]

18. Li, X.D.; Wu, J.; Gao, D.; Wang, H.; Sun, L.; Chen, Z.J. Pivotal roles of cGAS-cGAMP signaling in antiviral defense and immune adjuvant effects. Science 2013, 341, 1390-1394. [CrossRef] [PubMed]

19. Wu, J.; Sun, L.; Chen, X.; Du, F.; Shi, H.; Chen, C.; Chen, Z.J. Cyclic GMP-AMP is an endogenous second messenger in innate immune signaling by cytosolic DNA. Science 2013, 339, 826-830. [CrossRef] [PubMed]

20. Khoo, L.T.; Chen, L.Y. Role of the cGAS-STING pathway in cancer development and oncotherapeutic approaches. EMBO Rep. 2018, 19, e46935. [CrossRef] [PubMed]

21. Barber, G.N. STING: Infection, inflammation and cancer. Nat. Rev. Immunol. 2015, 15, 760-770. [CrossRef]

22. Feng, X.; Liu, D.; Li, Z.; Bian, J. Bioactive modulators targeting STING adaptor in cGAS-STING pathway. Drug. Discov. Today 2020, 25, 230-237. [CrossRef]

23. Honda, T.; Egawa, G.; Grabbe, S.; Kabashima, K. Update of immune events in the murine contact hypersensitivity model: Toward the understanding of allergic contact dermatitis. J. Investig. Derm. 2013, 133, 303-315. [CrossRef] [PubMed] 
24. Sawada, Y.; Honda, T.; Hanakawa, S.; Nakamizo, S.; Murata, T.; Ueharaguchi-Tanada, Y.; Ono, S.; Amano, W.; Nakajima, S.; Egawa, G.; et al. Resolvin E1 inhibits dendritic cell migration in the skin and attenuates contact hypersensitivity responses. J. Exp. Med. 2015, 212, 1921-1930. [CrossRef] [PubMed]

25. Sawada, Y.; Honda, T.; Nakamizo, S.; Nakajima, S.; Nonomura, Y.; Otsuka, A.; Egawa, G.; Yoshimoto, T.; Nakamura, M.; Narumiya, S.; et al. Prostaglandin E(2) (PGE(2))-EP2 signaling negatively regulates murine atopic dermatitis-like skin inflammation by suppressing thymic stromal lymphopoietin expression. J. Allergy Clin. Immunol. 2019, 144, 1265-1273.e9. [CrossRef]

26. Honda, T.; Yamamoto, O.; Sawada, Y.; Egawa, G.; Kitoh, A.; Otsuka, A.; Dainichi, T.; Nakajima, S.; Miyachi, Y.; Kabashima, K. Receptor-interacting protein kinase 3 controls keratinocyte activation in a necroptosis-independent manner and promotes psoriatic dermatitis in mice. J. Allergy Clin. Immunol. 2017, 140, 619-622.e6. [CrossRef] [PubMed]

27. Yoshioka, M.; Sawada, Y.; Saito-Sasaki, N.; Yoshioka, H.; Hama, K.; Omoto, D.; Ohmori, S.; Okada, E.; Nakamura, M. High S100A2 expression in keratinocytes in patients with drug eruption. Sci. Rep. 2021, 11, 5493. [CrossRef] [PubMed]

28. Ueharaguchi, Y.; Honda, T.; Kusuba, N.; Hanakawa, S.; Adachi, A.; Sawada, Y.; Otsuka, A.; Kitoh, A.; Dainichi, T.; Egawa, G.; et al. Thromboxane $\mathrm{A}_{2}$ facilitates IL-17A production from ${\mathrm{V} \gamma 4^{+}}_{\gamma} \delta \mathrm{T}$ cells and promotes psoriatic dermatitis in mice. J. Allergy Clin. Immunol. 2018, 142, 680-683.e2. [CrossRef]

29. Chiliveru, S.; Rahbek, S.H.; Jensen, S.K.; Jørgensen, S.E.; Nissen, S.K.; Christiansen, S.H.; Mogensen, T.H.; Jakobsen, M.R.; Iversen, L.; Johansen, C.; et al. Inflammatory cytokines break down intrinsic immunological tolerance of human primary keratinocytes to cytosolic DNA. J. Immunol. 2014, 192, 2395-2404. [CrossRef] [PubMed]

30. Yu, Y.; Xue, X.; Tang, W.; Su, L.; Zhang, L.; Zhang, Y. Cytosolic DNA-Mediated STING-Dependent Inflammation Contributes to the Progression of Psoriasis. J. Investig. Derm. 2021. [CrossRef] [PubMed]

31. Fischer, K.; Tschismarov, R.; Pilz, A.; Straubinger, S.; Carotta, S.; McDowell, A.; Decker, T. Cutibacterium acnes Infection Induces Type I Interferon Synthesis Through the cGAS-STING Pathway. Front. Immunol. 2020, 11, 571334. [CrossRef]

32. Orvain, C.; Lin, Y.L.; Jean-Louis, F.; Hocini, H.; Hersant, B.; Bennasser, Y.; Ortonne, N.; Hotz, C.; Wolkenstein, P.; Boniotto, M.; et al. Hair follicle stem cell replication stress drives IFI16/STING-dependent inflammation in hidradenitis suppurativa. J. Clin. Investig. 2020, 130, 3777-3790. [CrossRef] [PubMed]

33. Seth, R.; Messersmith, H.; Kaur, V.; Kirkwood, J.M.; Kudchadkar, R.; McQuade, J.L.; Provenzano, A.; Swami, U.; Weber, J.; Alluri, K.C.; et al. Systemic Therapy for Melanoma: ASCO Guideline. J. Clin. Oncol. 2020, 38, 3947-3970. [CrossRef] [PubMed]

34. Saito, R.; Sawada, Y.; Nakamura, M. Immune Profile Analysis in Peripheral Blood and Tumor in Patients with Malignant Melanoma. Int. J. Mol. Sci. 2021, 22, 1957. [CrossRef] [PubMed]

35. Saito, R.; Sawada, Y.; Saito-Sasaki, N.; Yamamoto, K.; Yoshioka, H.; Ohmori, S.; Yoshioka, M.; Okada, E.; Nakamura, M. Profile fluctuation of peripheral blood in advanced melanoma patients treated with nivolumab. J. Derm. 2018, 45, 1452-1455. [CrossRef] [PubMed]

36. Mashima, E.; Inoue, A.; Sakuragi, Y.; Yamaguchi, T.; Sasaki, N.; Hara, Y.; Omoto, D.; Ohmori, S.; Haruyama, S.; Sawada, Y.; et al. Nivolumab in the treatment of malignant melanoma: Review of the literature. Onco. Targets Ther. 2015, 8, $2045-2051$.

37. Muñoz, N.M.; Williams, M.; Dixon, K.; Dupuis, C.; McWatters, A.; Avritscher, R.; Manrique, S.Z.; McHugh, K.; Murthy, R.; Tam, A.; et al. Influence of injection technique, drug formulation and tumor microenvironment on intratumoral immunotherapy delivery and efficacy. J. Immunother. Cancer 2021, 9, e001800. [CrossRef] [PubMed]

38. Ahn, J.; Xia, T.; Rabasa Capote, A.; Betancourt, D.; Barber, G.N. Extrinsic Phagocyte-Dependent STING Signaling Dictates the Immunogenicity of Dying Cells. Cancer Cell 2018, 33, 862-873.e5. [CrossRef] [PubMed]

39. Si, W.; Liang, H.; Bugno, J.; Xu, Q.; Ding, X.; Yang, K.; Fu, Y.; Weichselbaum, R.R.; Zhao, X.; Wang, L. Lactobacillus rhamnosus GG induces cGAS/STING- dependent type I interferon and improves response to immune checkpoint blockade. Gut 2021. [CrossRef]

40. Chelvanambi, M.; Fecek, R.J.; Taylor, J.L.; Storkus, W.J. STING agonist-based treatment promotes vascular normalization and tertiary lymphoid structure formation in the therapeutic melanoma microenvironment. J. Immunother. Cancer 2021, 9, e001906. [CrossRef] [PubMed]

41. Chavanet, A.; Hill, K.R.; Jiménez-Andrade, Y.; Choo, M.K.; White, K.; Park, J.M. Intracellular signaling modules linking DNA damage to secretome changes in senescent melanoma cells. Melanoma Res. 2020, 30, 336-347. [CrossRef]

42. Wang, Z.; Celis, E. STING activator c-di-GMP enhances the anti-tumor effects of peptide vaccines in melanoma-bearing mice. Cancer Immunol. Immunother. 2015, 64, 1057-1066. [CrossRef]

43. Nakamura, T.; Miyabe, H.; Hyodo, M.; Sato, Y.; Hayakawa, Y.; Harashima, H. Liposomes loaded with a STING pathway ligand, cyclic di-GMP, enhance cancer immunotherapy against metastatic melanoma. J. Control. Release 2015, 216, 149-157. [CrossRef]

44. Falahat, R.; Perez-Villarroel, P.; Mailloux, A.W.; Zhu, G.; Pilon-Thomas, S.; Barber, G.N.; Mulé, J.J. STING Signaling in Melanoma Cells Shapes Antigenicity and Can Promote Antitumor T-cell Activity. Cancer Immunol. Res. 2019, 7, 1837-1848. [CrossRef]

45. Falahat, R.; Berglund, A.; Putney, R.M.; Perez-Villarroel, P.; Aoyama, S.; Pilon-Thomas, S.; Barber, G.N.; Mulé, J.J. Epigenetic reprogramming of tumor cell-intrinsic STING function sculpts antigenicity and T cell recognition of melanoma. Proc Natl. Acad. Sci. USA 2021, 118, e2013598118. [CrossRef] [PubMed]

46. Demaria, O.; De Gassart, A.; Coso, S.; Gestermann, N.; Di Domizio, J.; Flatz, L.; Gaide, O.; Michielin, O.; Hwu, P.; Petrova, T.V.; et al. STING activation of tumor endothelial cells initiates spontaneous and therapeutic antitumor immunity. Proc. Natl. Acad. Sci. USA 2015, 112, 15408-15413. [CrossRef] [PubMed] 
47. Takashima, K.; Takeda, Y.; Oshiumi, H.; Shime, H.; Okabe, M.; Ikawa, M.; Matsumoto, M.; Seya, T. STING in tumor and host cells cooperatively work for NK cell-mediated tumor growth retardation. Biochem. Biophys. Res. Commun. 2016, 478, 1764-1771. [CrossRef] [PubMed]

48. Francica, B.J.; Ghasemzadeh, A.; Desbien, A.L.; Theodros, D.; Sivick, K.E.; Reiner, G.L.; Hix Glickman, L.; Marciscano, A.E.; Sharabi, A.B.; Leong, M.L.; et al. TNF $\alpha$ and Radioresistant Stromal Cells Are Essential for Therapeutic Efficacy of Cyclic Dinucleotide STING Agonists in Nonimmunogenic Tumors. Cancer Immunol. Res. 2018, 6, 422-433. [CrossRef] [PubMed]

49. Wang, H.; Hu, S.; Chen, X.; Shi, H.; Chen, C.; Sun, L.; Chen, Z.J. cGAS is essential for the antitumor effect of immune checkpoint blockade. Proc. Natl. Acad. Sci. USA 2017, 114, 1637-1642. [CrossRef] [PubMed]

50. Ohkuri, T.; Kosaka, A.; Ishibashi, K.; Kumai, T.; Hirata, Y.; Ohara, K.; Nagato, T.; Oikawa, K.; Aoki, N.; Harabuchi, Y.; et al. Intratumoral administration of cGAMP transiently accumulates potent macrophages for anti-tumor immunity at a mouse tumor site. Cancer Immunol. Immunother. 2017, 66, 705-716. [CrossRef] [PubMed]

51. Smith, T.T.; Moffett, H.F.; Stephan, S.B.; Opel, C.F.; Dumigan, A.G.; Jiang, X.; Pillarisetty, V.G.; Pillai, S.P.S.; Wittrup, K.D.; Stephan, M.T. Biopolymers codelivering engineered T cells and STING agonists can eliminate heterogeneous tumors. J. Clin. Investig. 2017, 127, 2176-2191. [CrossRef] [PubMed]

52. Tian, J.; Zhang, D.; Kurbatov, V.; Wang, Q.; Wang, Y.; Fang, D.; Wu, L.; Bosenberg, M.; Muzumdar, M.D.; Khan, S.; et al. 5-Fluorouracil efficacy requires anti-tumor immunity triggered by cancer-cell-intrinsic STING. EMBO J. 2021, 40, e106065. [CrossRef] [PubMed]

53. Hou, Y.; Liang, H.L.; Yu, X.; Liu, Z.; Cao, X.; Rao, E.; Huang, X.; Wang, L.; Li, L.; Bugno, J.; et al. Radiotherapy and immunotherapy converge on elimination of tumor-promoting erythroid progenitor cells through adaptive immunity. Sci. Transl. Med. 2021, 13. [CrossRef]

54. Harding, S.M.; Benci, J.L.; Irianto, J.; Discher, D.E.; Minn, A.J.; Greenberg, R.A. Mitotic progression following DNA damage enables pattern recognition within micronuclei. Nature 2017, 548, 466-470. [CrossRef]

55. Hou, Y.; Liang, H.; Rao, E.; Zheng, W.; Huang, X.; Deng, L.; Zhang, Y.; Yu, X.; Xu, M.; Mauceri, H.; et al. Non-canonical NF-kB Antagonizes STING Sensor-Mediated DNA Sensing in Radiotherapy. Immunity 2018, 49, 490-503.e4. [CrossRef] [PubMed]

56. Saito-Sasaki, N.; Sawada, Y.; Okada, E.; Nakamura, M. Cell Adhesion Molecule 1 (CADM1) Is an Independent Prognostic Factor in Patients with Cutaneous Squamous Cell Carcinoma. Diagnostics 2021, 11, 830. [CrossRef] [PubMed]

57. Sawada, Y.; Nakamura, M. Daily Lifestyle and Cutaneous Malignancies. Int. J. Mol. Sci. 2021, 22, 5227. [CrossRef] [PubMed]

58. Sawada, Y.; Mashima, E.; Saito-Sasaki, N.; Nakamura, M. The Role of Cell Adhesion Molecule 1 (CADM1) in Cutaneous Malignancies. Int. J. Mol. Sci. 2020, 21, 9732. [CrossRef]

59. Hayman, T.J.; Baro, M.; MacNeil, T.; Phoomak, C.; Aung, T.N.; Cui, W.; Leach, K.; Iyer, R.; Challa, S.; Sandoval-Schaefer, T.; et al. STING enhances cell death through regulation of reactive oxygen species and DNA damage. Nat. Commun. 2021, 12, 2327. [CrossRef] [PubMed]

60. Wang, Z.C.; Zhang, L.; Li, Z.L.; He, J.; Cai, T.T.; Yang, D.J.; Xie, D.R. Expression of STING and MIF in tumor infiltration lymphocytes as prognostic factors in patients with ESCC. Int. J. Clin. Exp. Pathol. 2017, 10, 10066-10074.

61. Baird, J.R.; Bell, R.B.; Troesch, V.; Friedman, D.; Bambina, S.; Kramer, G.; Blair, T.C.; Medler, T.; Wu, Y.; Sun, Z.; et al. Evaluation of Explant Responses to STING Ligands: Personalized Immunosurgical Therapy for Head and Neck Squamous Cell Carcinoma. Cancer Res. 2018, 78, 6308-6319. [CrossRef] [PubMed]

62. Liang, D.; Xiao-Feng, H.; Guan-Jun, D.; Er-Ling, H.; Sheng, C.; Ting-Ting, W.; Qin-Gang, H.; Yan-Hong, N.; Ya-Yi, H. Activated STING enhances Tregs infiltration in the HPV-related carcinogenesis of tongue squamous cells via the c-jun/CCL22 signal. Biochim. Biophys. Acta 2015, 1852, 2494-2503.

63. Bakhoum, S.F.; Ngo, B.; Laughney, A.M.; Cavallo, J.A.; Murphy, C.J.; Ly, P.; Shah, P.; Sriram, R.K.; Watkins, T.B.K.; Taunk, N.K.; et al. Chromosomal instability drives metastasis through a cytosolic DNA response. Nature 2018, 553, 467-472. [CrossRef] [PubMed]

64. Harabuchi, S.; Kosaka, A.; Yajima, Y.; Nagata, M.; Hayashi, R.; Kumai, T.; Ohara, K.; Nagato, T.; Oikawa, K.; Ohara, M.; et al. Intratumoral STING activations overcome negative impact of cisplatin on antitumor immunity by inflaming tumor microenvironment in squamous cell carcinoma. Biochem. Biophys. Res. Commun. 2020, 522, 408-414. [CrossRef]

65. Lu, S.; Concha-Benavente, F.; Shayan, G.; Srivastava, R.M.; Gibson, S.P.; Wang, L.; Gooding, W.E.; Ferris, R.L. STING activation enhances cetuximab-mediated NK cell activation and DC maturation and correlates with HPV(+) status in head and neck cancer. Oral. Oncol. 2018, 78, 186-193. [CrossRef]

66. Krump, N.A.; Wang, R.; Liu, W.; Yang, J.F.; Ma, T.; You, J. Merkel Cell Polyomavirus Infection Induces an Antiviral Innate Immune Response in Human Dermal Fibroblasts. J. Virol. 2021, 95, e0221120. [CrossRef] [PubMed]

67. Liu, W.; Kim, G.B.; Krump, N.A.; Zhou, Y.; Riley, J.L.; You, J. Selective reactivation of STING signaling to target Merkel cell carcinoma. Proc. Natl. Acad. Sci. USA 2020, 117, 13730-13739. [CrossRef] [PubMed]

68. Willemze, R.; Jaffe, E.S.; Burg, G.; Cerroni, L.; Berti, E.; Swerdlow, S.H.; Ralfkiaer, E.; Chimenti, S.; Diaz-Perez, J.L.; Duncan, L.M.; et al. WHO-EORTC classification for cutaneous lymphomas. Blood 2005, 105, 3768-3785. [CrossRef] [PubMed]

69. Cook, L.B.; Fuji, S.; Hermine, O.; Bazarbachi, A.; Ramos, J.C.; Ratner, L.; Horwitz, S.; Fields, P.; Tanase, A.; Bumbea, H.; et al. Revised Adult T-Cell Leukemia-Lymphoma International Consensus Meeting Report. J. Clin. Oncol. 2019, 37, 677-687. [CrossRef] [PubMed]

70. Sawada, Y.; Hino, R.; Hama, K.; Ohmori, S.; Fueki, H.; Yamada, S.; Fukamachi, S.; Tajiri, M.; Kubo, R.; Yoshioka, M.; et al. Type of skin eruption is an independent prognostic indicator for adult T-cell leukemia/lymphoma. Blood 2011, 117, 3961-3967. [CrossRef] [PubMed] 
71. Sawada, Y.; Shimauchi, T.; Yamaguchi, T.; Okura, R.; Hama-Yamamoto, K.; Fueki-Yoshioka, H.; Ohmori, S.; Yamada, S.; Yoshizawa, M.; Hiromasa, K.; et al. Combination of skin-directed therapy and oral etoposide for smoldering adult T-cell leukemia/lymphoma with skin involvement. Leuk Lymphoma 2013, 54, 520-527. [CrossRef] [PubMed]

72. Tokura, Y.; Sawada, Y.; Shimauchi, T. Skin manifestations of adult T-cell leukemia/lymphoma: Clinical, cytological and immunological features. J. Derm. 2014, 41, 19-25. [CrossRef] [PubMed]

73. Yamada, Y.; Tomonaga, M.; Fukuda, H.; Hanada, S.; Utsunomiya, A.; Tara, M.; Sano, M.; Ikeda, S.; Takatsuki, K.; Kozuru, M.; et al. A new G-CSF-supported combination chemotherapy, LSG15, for adult T-cell leukaemia-lymphoma: Japan Clinical Oncology Group Study 9303. Br. J. Haematol. 2001, 113, 375-382. [CrossRef] [PubMed]

74. Tsukasaki, K.; Utsunomiya, A.; Fukuda, H.; Shibata, T.; Fukushima, T.; Takatsuka, Y.; Ikeda, S.; Masuda, M.; Nagoshi, H.; Ueda, R.; et al. VCAP-AMP-VECP compared with biweekly CHOP for adult T-cell leukemia-lymphoma: Japan Clinical Oncology Group Study JCOG9801. J. Clin. Oncol. 2007, 25, 5458-5464. [CrossRef] [PubMed]

75. Stanchina, M.; Soong, D.; Zheng-Lin, B.; Watts, J.M.; Taylor, J. Advances in Acute Myeloid Leukemia: Recently Approved Therapies and Drugs in Development. Cancers 2020, 12, 3225. [CrossRef] [PubMed]

76. Bladé, J.; Dimopoulos, M.; Rosiñol, L.; Rajkumar, S.V.; Kyle, R.A. Smoldering (asymptomatic) multiple myeloma: Current diagnostic criteria, new predictors of outcome, and follow-up recommendations. J. Clin. Oncol. 2010, 28, 690-697. [CrossRef] [PubMed]

77. Yuen, C.K.; Chan, C.P.; Fung, S.Y.; Wang, P.H.; Wong, W.M.; Tang, H.V.; Yuen, K.S.; Chan, C.P.; Jin, D.Y.; Kok, K.H. Suppression of Type I Interferon Production by Human T-Cell Leukemia Virus Type 1 Oncoprotein Tax through Inhibition of IRF3 Phosphorylation. J. Virol. 2016, 90, 3902-3912. [CrossRef] [PubMed]

78. Sze, A.; Belgnaoui, S.M.; Olagnier, D.; Lin, R.; Hiscott, J.; van Grevenynghe, J. Host restriction factor SAMHD1 limits human $\mathrm{T}$ cell leukemia virus type 1 infection of monocytes via STING-mediated apoptosis. Cell Host Microbe 2013, 14, 422-434. [CrossRef] [PubMed]

79. Buechner, S.A.; Wernli, M.; Harr, T.; Hahn, S.; Itin, P.; Erb, P. Regression of basal cell carcinoma by intralesional interferon-alpha treatment is mediated by CD95 (Apo-1/Fas)-CD95 ligand-induced suicide. J. Clin. Investig. 1997, 100, 2691-2696. [CrossRef]

80. Li, C.; Chi, S.; He, N.; Zhang, X.; Guicherit, O.; Wagner, R.; Tyring, S.; Xie, J. IFNalpha induces Fas expression and apoptosis in hedgehog pathway activated BCC cells through inhibiting Ras-Erk signaling. Oncogene 2004, 23, 1608-1617. [CrossRef]

81. Wong, D.A.; Bishop, G.A.; Lowes, M.A.; Cooke, B.; Barnetson, R.S.; Halliday, G.M. Cytokine profiles in spontaneously regressing basal cell carcinomas. Br. J. Derm. 2000, 143, 91-98. [CrossRef] [PubMed]

82. Oehadian, A.; Koide, N.; Mu, M.M.; Hassan, F.; Islam, S.; Yoshida, T.; Yokochi, T. Interferon (IFN)-beta induces apoptotic cell death in DHL-4 diffuse large B cell lymphoma cells through tumor necrosis factor-related apoptosis-inducing ligand (TRAIL). Cancer Lett. 2005, 225, 85-92. [CrossRef]

83. Jumbou, O.; N'Guyen, J.M.; Tessier, M.H.; Legoux, B.; Dréno, B. Long-term follow-up in 51 patients with mycosis fungoides and Sézary syndrome treated by interferon-alfa. Br. J. Derm. 1999, 140, 427-431. [CrossRef]

84. Dréno, B.; Claudy, A.; Meynadier, J.; Verret, J.L.; Souteyrand, P.; Ortonne, J.P.; Kalis, B.; Godefroy, W.Y.; Beerblock, K.; Thill, L. The treatment of 45 patients with cutaneous T-cell lymphoma with low doses of interferon-alpha 2a and etretinate. Br. J. Derm. 1991, 125, 456-459. [CrossRef] [PubMed]

85. Yano, H.; Ishida, T.; Inagaki, A.; Ishii, T.; Ding, J.; Kusumoto, S.; Komatsu, H.; Iida, S.; Inagaki, H.; Ueda, R. Defucosylated anti CC chemokine receptor 4 monoclonal antibody combined with immunomodulatory cytokines: A novel immunotherapy for aggressive/refractory Mycosis fungoides and Sezary syndrome. Clin. Cancer Res. 2007, 13, 6494-6500. [CrossRef] [PubMed]

86. Rupoli, S.; Barulli, S.; Guiducci, B.; Offidani, M.; Mozzicafreddo, G.; Simonacci, M.; Filosa, G.; Giacchetti, A.; Ricotti, G.; Brandozzi, G.; et al. Low dose interferon-alpha2b combined with PUVA is an effective treatment of early stage mycosis fungoides: Results of a multicenter study. Cutaneous-T Cell Lymphoma Multicenter Study Group. Haematologica 1999, 84, 809-813.

87. Ständer, H.; Ständer, S.; Luger, T.; Schwarz, T. Topical interferon-beta: An additional treatment for ulcerated mycosis fungoides. Hautarzt 2001, 52, 882-884.

88. Yamamoto, T.; Sasaki, G.; Sato, T.; Katayama, I.; Nishioka, K. Cytokine profile of tumor cells in mycosis fungoides: Successful treatment with intra-lesional interferon-gamma combined with chemotherapy. J. Derm. 1995, 22, 650-654. [CrossRef] [PubMed]

89. Horikoshi, T.; Onodera, H.; Eguchi, H.; Hanada, N.; Fukuzawa, K.; Takahashi, M.; Ishihara, K.; Ikeda, S. A patient with plaquestage mycosis fungoides has successfully been treated with long-term administration of IFN-gamma and has been in complete remission for more than 6 years. Br. J. Derm. 1996, 134, 130-133. [CrossRef]

90. Yamamoto, T.; Takahashi, Y.; Katayama, I.; Nishioka, K. Alteration of cytokine genes and bcl-2 expression following immunotherapy with intralesional IFN-gamma in a patient with tumor-stage mycosis fungoides. Dermatology 1998, 196, 283-287. [CrossRef] [PubMed]

91. Kohn, E.C.; Steis, R.G.; Sausville, E.A.; Veach, S.R.; Stocker, J.L.; Phelps, R.; Franco, S.; Longo, D.L.; Bunn, P.A.; Ihde, D.C. Phase II trial of intermittent high-dose recombinant interferon alfa-2a in mycosis fungoides and the Sézary syndrome. J. Clin. Oncol. 1990, 8, 155-160. [CrossRef]

92. Foss, F.M.; Ihde, D.C.; Breneman, D.L.; Phelps, R.M.; Fischmann, A.B.; Schechter, G.P.; Linnoila, I.; Breneman, J.C.; Cotelingam, J.D.; Ghosh, B.C.; et al. Phase II study of pentostatin and intermittent high-dose recombinant interferon alfa-2a in advanced mycosis fungoides/Sézary syndrome. J. Clin. Oncol. 1992, 10, 1907-1913. [CrossRef]

93. Sanli, H.; Akay, B.N.; Anadolu, R.; Ozcan, M.; Saral, S.; Akyol, A. The efficacy of vorinostat in combination with interferon alpha and extracorporeal photopheresis in late stage mycosis fungoides and Sezary syndrome. J. Drugs Derm. 2011, 10, 403-408. 
94. Chiarion-Sileni, V.; Bononi, A.; Fornasa, C.V.; Soraru, M.; Alaibac, M.; Ferrazzi, E.; Redelotti, R.; Peserico, A.; Monfardini, S.; Salvagno, L. Phase II trial of interferon-alpha-2a plus psolaren with ultraviolet light A in patients with cutaneous T-cell lymphoma. Cancer 2002, 95, 569-575. [CrossRef]

95. Seo, N.; Tokura, Y.; Matsumoto, K.; Furukawa, F.; Takigawa, M. Tumour-specific cytotoxic T lymphocyte activity in Th2-type Sézary syndrome: Its enhancement by interferon-gamma (IFN-gamma) and IL-12 and fluctuations in association with disease activity. Clin. Exp. Immunol. 1998, 112, 403-409. [CrossRef]

96. Becker, J.C.; Zur Hausen, A. Cells of origin in skin cancer. J. Investig. Derm. 2014, 134, 2491-2493. [CrossRef]

97. Crombie, J.L.; Armand, P. Diffuse Large B-Cell Lymphoma's New Genomics: The Bridge and the Chasm. J. Clin. Oncol. 2020, 38, 3565-3574. [CrossRef] [PubMed]

98. Vermeer, M.H.; Nicolay, J.P.; Scarisbrick, J.J.; Zinzani, P.L. The importance of assessing blood tumour burden in cutaneous T-cell lymphoma. Br. J. Derm. 2021, 185, 19-25. [CrossRef]

99. Quaglino, P.; Fava, P.; Pileri, A.; Grandi, V.; Sanlorenzo, M.; Panasiti, V.; Guglielmo, A.; Alberti-Violetti, S.; Novelli, M.; Astrua, C.; et al. Phenotypical Markers, Molecular Mutations, and Immune Microenvironment as Targets for New Treatments in Patients with Mycosis Fungoides and/or Sézary Syndrome. J. Investig. Derm. 2021, 141, 484-495. [CrossRef]

100. Mashima, E.; Sawada, Y.; Yamaguchi, T.; Yoshioka, H.; Ohmori, S.; Haruyama, S.; Yoshioka, M.; Okada, E.; Nakamura, M. A high expression of cell adhesion molecule 1 (CADM1) is an unfavorable prognostic factor in mycosis fungoides. Clin. Immunol. 2018, 193, 121-122. [CrossRef]

101. Sawada, Y.; Sugita, K.; Kabashima, R.; Hino, R.; Nakamura, M.; Koga, C.; Tokura, Y. CD8+ CD56+ mycosis fungoides with an indolent clinical behaviour: Case report and literature review. Acta Derm. Venereol. 2010, 90, 525-526. [CrossRef] [PubMed]

102. Wieselthier, J.S.; Koh, H.K. Sézary syndrome: Diagnosis, prognosis, and critical review of treatment options. J. Am. Acad. Derm. 1990, 22, 381-401. [CrossRef]

103. Koshy, S.T.; Cheung, A.S.; Gu, L.; Graveline, A.R.; Mooney, D.J. Liposomal Delivery Enhances Immune Activation by STING Agonists for Cancer Immunotherapy. Adv. Biosyst. 2017, 1, 1600013. [CrossRef]

104. Wilson, D.R.; Sen, R.; Sunshine, J.C.; Pardoll, D.M.; Green, J.J.; Kim, Y.J. Biodegradable STING agonist nanoparticles for enhanced cancer immunotherapy. Nanomedicine 2018, 14, 237-246. [CrossRef] [PubMed]

105. Li, K.; Ye, Y.; Liu, L.; Sha, Q.; Wang, X.; Jiao, T.; Zhang, L.; Wang, J. The lipid platform increases the activity of STING agonists to synergize checkpoint blockade therapy against melanoma. Biomater. Sci. 2021, 9, 765-773. [CrossRef] [PubMed]

106. Lu, X.; Miao, L.; Gao, W.; Chen, Z.; McHugh, K.J.; Sun, Y.; Tochka, Z.; Tomasic, S.; Sadtler, K.; Hyacinthe, A.; et al. Engineered PLGA microparticles for long-term, pulsatile release of STING agonist for cancer immunotherapy. Sci. Transl. Med. 2020 12, eaaz6606. [CrossRef] [PubMed]

107. Chen, C.; Tong, Y.; Zheng, Y.; Shi, Y.; Chen, Z.; Li, J.; Liu, X.; Zhang, D.; Yang, H. Cytosolic Delivery of Thiolated Mn-cGAMP Nanovaccine to Enhance the Antitumor Immune Responses. Small 2021, 17, e2006970. [CrossRef] [PubMed]

108. Chipurupalli, S.; Ganesan, R.; Dhanabal, S.P.; Kumar, M.S.; Robinson, N. Pharmacological STING Activation Is a Potential Alternative to Overcome Drug-Resistance in Melanoma. Front. Oncol. 2020, 10, 758. [CrossRef]

109. Wilski, N.A.; Stotesbury, C.; Del Casale, C.; Montoya, B.; Wong, E.; Sigal, L.J.; Snyder, C.M. STING Sensing of Murine Cytomegalovirus Alters the Tumor Microenvironment to Promote Antitumor Immunity. J. Immunol. 2020, 204, 2961-2972. [CrossRef] [PubMed]

110. Ager, C.R.; Zhang, H.; Wei, Z.; Jones, P.; Curran, M.A.; Di Francesco, M.E. Discovery of IACS-8803 and IACS-8779, potent agonists of stimulator of interferon genes (STING) with robust systemic antitumor efficacy. Bioorg. Med. Chem. Lett. 2019, 29, 126640. [CrossRef]

111. Melms, J.C.; Vallabhaneni, S.; Mills, C.E.; Yapp, C.; Chen, J.Y.; Morelli, E.; Waszyk, P.; Kumar, S.; Deming, D.; Moret, N.; et al. Inhibition of Haspin Kinase Promotes Cell-Intrinsic and Extrinsic Antitumor Activity. Cancer Res. 2020, 80, 798-810. [CrossRef]

112. Sivick, K.E.; Desbien, A.L.; Glickman, L.H.; Reiner, G.L.; Corrales, L.; Surh, N.H.; Hudson, T.E.; Vu, U.T.; Francica, B.J.; Banda, T.; et al. Magnitude of Therapeutic STING Activation Determines CD8(+) T Cell-Mediated Anti-tumor Immunity. Cell Rep. 2018, 25, 3074-3085.e5. [CrossRef] [PubMed]

113. Shi, F.; Su, J.; Wang, J.; Liu, Z.; Wang, T. Activation of STING inhibits cervical cancer tumor growth through enhancing the anti-tumor immune response. Mol. Cell. Biochem. 2021, 476, 1015-1024. [CrossRef]

114. Vonderhaar, E.P.; Barnekow, N.S.; McAllister, D.; McOlash, L.; Eid, M.A.; Riese, M.J.; Tarakanova, V.L.; Johnson, B.D.; Dwinell, M.B. STING Activated Tumor-Intrinsic Type I Interferon Signaling Promotes CXCR3 Dependent Antitumor Immunity in Pancreatic Cancer. Cell. Mol. Gastroenterol. Hepatol. 2021, 12, 41-58. [CrossRef] [PubMed]

115. Zaidi, A.H.; Kelly, R.J.; Gorbunova, A.; Omstead, A.N.; Salvitti, M.S.; Zheng, P.; Kosovec, J.E.; Lee, S.; Ayazi, S.; Babar, L.; et al Intratumoral immunotherapy with STING agonist, ADU-S100, induces CD8+ T-cell mediated anti-tumor immunity in an esophageal adenocarcinoma model. Oncotarget 2021, 12, 292-303. [CrossRef]

116. Lu, Z.D.; Chen, Y.F.; Shen, S.; Xu, C.F.; Wang, J. Co-delivery of Phagocytosis Checkpoint Silencer and Stimulator of Interferon Genes Agonist for Synergetic Cancer Immunotherapy. ACS Appl. Mater. Interfaces 2021, 13, 29424-29438. [CrossRef]

117. Levy, E.S.; Chang, R.; Zamecnik, C.R.; Dhariwala, M.O.; Fong, L.; Desai, T.A. Multi-Immune Agonist Nanoparticle Therapy Stimulates Type I Interferons to Activate Antigen-Presenting Cells and Induce Antigen-Specific Antitumor Immunity. Mol. Pharm. 2021, 18, 1014-1025. [CrossRef] [PubMed]

118. Tan, Y.S.; Sansanaphongpricha, K.; Xie, Y.; Donnelly, C.R.; Luo, X.; Heath, B.R.; Zhao, X.; Bellile, E.; Hu, H.; Chen, H.; et al. Mitigating SOX2-potentiated Immune Escape of Head and Neck Squamous Cell Carcinoma with a STING-inducing Nanosatellite Vaccine. Clin. Cancer Res. 2018, 24, 4242-4255. [CrossRef] [PubMed] 
119. Luo, X.; Donnelly, C.R.; Gong, W.; Heath, B.R.; Hao, Y.; Donnelly, L.A.; Moghbeli, T.; Tan, Y.S.; Lin, X.; Bellile, E.; et al. HPV16 drives cancer immune escape via NLRX1-mediated degradation of STING. J. Clin. Investig. 2020, 130, 1635-1652. [CrossRef] [PubMed]

120. Sawada, Y.; Gallo, R.L. Role of Epigenetics in the Regulation of Immune Functions of the Skin. J. Investig. Derm. 2021, 141, 1157-1166. [CrossRef] [PubMed]

121. Xia, T.; Konno, H.; Barber, G.N. Recurrent Loss of STING Signaling in Melanoma Correlates with Susceptibility to Viral Oncolysis. Cancer Res. 2016, 76, 6747-6759. [CrossRef] [PubMed]

122. Konno, H.; Yamauchi, S.; Berglund, A.; Putney, R.M.; Mulé, J.J.; Barber, G.N. Suppression of STING signaling through epigenetic silencing and missense mutation impedes DNA damage mediated cytokine production. Oncogene 2018, 37, 2037-2051. [CrossRef] [PubMed]

123. Zhang, W.; Liu, W.; Jia, L.; Chen, D.; Chang, I.; Lake, M.; Bentolila, L.A.; Wang, C.Y. Targeting KDM4A epigenetically activates tumor-cell-intrinsic immunity by inducing DNA replication stress. Mol. Cell 2021, 81, 2148-2165.e9. [CrossRef] [PubMed]

124. Yamashiro, L.H.; Wilson, S.C.; Morrison, H.M.; Karalis, V.; Chung, J.J.; Chen, K.J.; Bateup, H.S.; Szpara, M.L.; Lee, A.Y.; Cox, J.S.; et al. Interferon-independent STING signaling promotes resistance to HSV-1 in vivo. Nat. Commun. 2020, 11, 3382. [CrossRef]

125. Wu, J.; Dobbs, N.; Yang, K.; Yan, N. Interferon-Independent Activities of Mammalian STING Mediate Antiviral Response and Tumor Immune Evasion. Immunity 2020, 53, 115-126.e5. [CrossRef] [PubMed]

126. Banerjee, D.; Langberg, K.; Abbas, S.; Odermatt, E.; Yerramothu, P.; Volaric, M.; Reidenbach, M.A.; Krentz, K.J.; Rubinstein, C.D.; Brautigan, D.L.; et al. A non-canonical, interferon-independent signaling activity of cGAMP triggers DNA damage response signaling. Nat. Commun. 2021, 12, 6207. [CrossRef] [PubMed]

127. Zebertavage, L.K.; Alice, A.; Crittenden, M.R.; Gough, M.J. Transcriptional Upregulation of NLRC5 by Radiation Drives STING- and Interferon-Independent MHC-I Expression on Cancer Cells and T Cell Cytotoxicity. Sci. Rep. 2020, 10, 7376. [CrossRef] [PubMed]

128. Tansakul, M.; Thim-Uam, A.; Saethang, T.; Makjaroen, J.; Wongprom, B.; Pisitkun, T.; Pisitkun, P. Deficiency of STING Promotes Collagen-Specific Antibody Production and B Cell Survival in Collagen-Induced Arthritis. Front. Immunol. 2020, 11, 1101. [CrossRef] [PubMed]

129. Li, Y.; Bax, C.; Patel, J.; Vazquez, T.; Ravishankar, A.; Bashir, M.M.; Grinnell, M.; Diaz, D.; Werth, V.P. Plasma-derived DNA containing-extracellular vesicles induce STING-mediated proinflammatory responses in dermatomyositis. Theranostics 2021, 11, 7144-7158. [CrossRef]

130. Oda, T.; Sawada, Y.; Okada, E.; Yamaguchi, T.; Ohmori, S.; Haruyama, S.; Yoshioka, M.; Nakamura, M. Hypopituitarism and hypothyroidism following atrioventricular block during nivolumab treatment. J. Derm. 2017, 44, e144-e145. [CrossRef] [PubMed]

131. Kivisäkk, P.; Alm, G.V.; Fredrikson, S.; Link, H. Neutralizing and binding anti-interferon-beta (IFN-beta) antibodies. A comparison between IFN-beta-1a and IFN-beta-1b treatment in multiple sclerosis. Eur. J. Neurol. 2000, 7, 27-34. [CrossRef] [PubMed]

132. Ahn, J.; Xia, T.; Konno, H.; Konno, K.; Ruiz, P.; Barber, G.N. Inflammation-driven carcinogenesis is mediated through STING. Nat. Commun. 2014, 5, 5166. [CrossRef] [PubMed] 